Цитування на цю статтю:

Бондаренко ІГ, Андрющенко МІ, Маєр ВЯ, Кураса ГО, Бондаренко ОВ. Оцінка ефективності організації дистанційного навчання майбутніх фахівців з фізичної культури. Вісник Прикарпатського університету. Серія: Фізична культура. 2020 Листоп 03; 35: 9-17

Відомості про автора:

Бондаренко Ірина Григорівна - кандидат наук 3 фізичного виховання та спорту, доцент, завідувач кафедри теорії та методики фізичного виховання, Чорноморський національний університет ім. Петра Могили (Миколаїв, Україна) https://orcid.org/0000-0002-6651-0682

Андрющенко Марина Іванівна - старший викладач кафедри теорії та методики фізичного виховання, Чорноморський національний університет ім. Петра Могили (Миколаїв, Україна) https://orcid.org/0000-0001-5895-7911

Маср Василь Якович - старший викладач кафедри теорії та методики фізичного виховання, Чорноморський національний університет ім. Петра Могили (Миколаїв, Україна) https://orcid.org/0000-0002-3108-4716

Кураса Геннадій Олександрович - старший викладач кафедри теорії та методики фізичного виховання, Чорноморський національний університет ім. Петра Могили (Миколаїв, Україна) https://orcid.org/0000-0001-5834-4509

Бондаренко Олег Володимирович - викладач кафедри теорії та методики фізичного виховання, Чорноморський національний університет ім. Петра Могили (Миколаїв, Україна)

e-mail: bondarenko.oleg.13.68@gmail.com

https://orcid.org/0000-0002-4995-7028
Information about the author:

Bondarenko Iryna Hryhorivna - $\mathrm{PhD}$ (Physical Education and Sport), Associate Professor, Head of the Department of Theory and Methods of Physical Education, Petro Mohyla Black Sea National University (Mykolaiv, Ukraine)

Andryushchenko Maryna Ivanivna - Senior Lecturer of the Department of Theory and Methods of Physical Education; Petro Mohyla Black Sea National University (Mykolaiv, Ukraine)

Mayer Vasyl' Yakovych - Senior Lecturer of the Department of Theory and Methods of Physical Education; Petro Mohyla Black Sea National University (Mykolaiv, Ukraine)

Kurasa Hennadiy Oleksandrovych - Senior Lecturer of the Department of Theory and Methods of Physical Education; Petro Mohyla Black Sea National University (Mykolaiv, Ukraine)

Mayer Vasyl'Yakovych - Lecturer of the Department of Theory and Methods of Physical Education; Petro Mohyla Black Sea National University (Mykolaiv, Ukraine)

\title{
ВПЛИВ ЗМІНИ ЧАСОВИХ ПОЯСІВ НА ПСИХОФІЗІОЛОГІЧНИЙ СТАН КВАЛІФІКОВАНИХ ФРИСТАЙЛІСТІВ
}

\begin{abstract}
Мета. Вивчити вплив зміни часових поясів на динаміку психофізіологічних показників кваліфікованих фристайлістів. Методи. Під час дослідження використані такі методи: теоретичний аналіз; педагогічний експеримент; тестування та анкетування; фізіологічні та психологічні тести; методи математичної статистики. У досліджені брали участь десять кваліфікованих фристайлістів. Результати. Анкетування кваліфікованих фристайлістів свідчать, щуо усі вони відчувають погіршення психофізіологічного стану власного організму при зміні часових поясів. У більшості опитаних спортсменів знижуються: працездатність, фізичні кондииї, техніка та координація рухів; погіриується сон, апетит, самопочуття та настрій. Спортсменам потрібно до тижня часу, щзоб адаптуватися до нового часового поясу та вийти на оптимальний стан власного організму. Педагогічний експерименту дозволили з'ясувати, щз у кваліфікованих фристайлістів при перельоті в західному напрямку найбільше зниження функціональних показників (фізичної працездатності, адаптаційного потенціалу, координації рухів), та психоемочійного стану (самопочуття, активності, настрою) припадає на третій день перебування та поступове їх відновлення до семи днів. Результати фізіологічних, педагогічних та психологічних досліджень кваліфікованих фристайлістів значною мірою співпадають з даними анкетування щзодо суб'єктивної оцінки стану свого організму при зміні часових поясів, а також з даними науковометодичної літератури присвяченими цій проблемі. Висновок. Під час зміни часових поясів у кваліфі-
\end{abstract}


кованих фристайлістів відбувається погіршення психофізіологічного стану, а саме: знижується фізична працездатність, здатність до точного виконання технічних елементів, координація рухів; погіршується сон, апетит, самопочуття та настрій. Як правило нормалізаџія всіх показників наступає після сьомого дня перебування в новому часовому поясі.

Ключові слова: психофізіологічний стан, адаптаџія, зміна часового поясу, кваліфіковані фристайлісти, працездатність.

The aim of the study to learn the influence of the time zones change on the dynamics of the psychophysiological indicators of the qualified freestylers. Methods: theoretical analysis and generalization of data from scientific and methodological literature; pedagogical experiment, pedagogical testing, questionnaires; physiological and psychological tests; methods of mathematical statistics. The study involved ten qualified freestylers. Results. Questionnaires of qualified freestylers show that they all experience a deterioration in the psychophysiological state of their own body when changing time zones. In most of the surveyed athletes are reduced: performance, physical condition, technique and coordination of movements; deteriorating sleep, appetite, well-being and mood. Athletes need up to a week to adapt to the new time zone and reach the optimal state of their body. Pedagogical experiment allowed to find out that qualified freestylers when flying in the western direction the greatest decrease in functional indicators (physical performance, adaptive capacity, coordination of movements), and psycho-emotional state (well-being, activity, mood) occurs on the third day of stay and their gradual recovery up to seven days. he results of physiological, pedagogical and psychological research of qualified freestylers largely coincide with the data of the questionnaire on the subjective assessment of the state of their body when changing time zones, as well as with the data of scientific and methodological literature on this problem. Conclusion. During the change of time zones in qualified freestylers there is a deterioration of the psychophysiological state, namely: reduced physical performance, the ability to accurately perform technical elements, coordination of movements; deteriorating sleep, appetite, well-being and mood. As a rule, the normalization of all indicators occurs after the seventh day of stay in the new time zone.

Keywords: psychophysiological state, adaptation, time zone change, qualified freestylers, efficiency.

Постановка проблеми та аналіз результатів останніх досліджень. Географія спорту, супроводжується збільшенням числа відповідальних змагань, що проводяться в різних поясо-кліматичних зонах. Багато з них проводяться на континентах, розташованих на відстані багатьох часових поясів, що характеризуються значними кліматичними контрастами. У таких умовах великого значення набуває прогнозування функціонального стану спортсменів, визначення термінів вильоту до місць змагань, розробка засобів методів тренування, організаційних медико-біологічних заходів, направлених на прискорення процесу адаптації, оптимізацію рухового режиму, підвищення працездатності $[2,5,6,12]$.

Календар змагань кваліфікованих спортсменів-фристайлістів також містить старти у різних часових поясах (Казахстан, Канада, США, Південна Корея, Японія). Дуже часто спортсмени беруть участь у змаганнях не пройшовши повноцінної адаптації до нових умов середовища $[1,3,7]$. А як наслідок, їм не вдається проявити свої максимальні можливості. Одна 3 причин такої ситуації є недостатнє фінансування команди для проведення повноцінної навчально-тренувальних зборів, безпосередньо на місцевості для адаптації до місцевого часу та кліматично-географічних умов. За даними науково-методичної літератури представникам різних видів спорту, для повноцінної адаптації, потрібно від 10 до 15 днів [4, 6].

Зміни, що відбуваються в системах організму спортсмена при зазначених впливах, вимагають особливих умов для адаптації. Найважливіше завдання, яке повинно вирішуватися на етапах перельоту та акліматизації - це збереження загальної та спеціальної працездатності [8].

Аналіз науково-методичної літератури показав, що у в роботах як вітчизняних, так зарубіжних авторів основна увага 3 даної проблеми приділяється дезадаптаційним зрушенням, які зумовленні різницею у часовому поясі представників різних видів спорту: швидкісних, силових, спортивних ігор, витривалості (лижників, біатлоністів, плавців, тенісистів тощо) $[9,10]$. Проте відсутня інформації щодо зміни працездатності 
та особливостей адаптації при зміні часового пояса представників фристайлу (як складнокоординаційного виду спорту). Але, як показує аналіз виступів спортсменів-фристайлістів на змаганнях, швидка зміна часового пояса, недостатній час для адаптації негативно позначається на самопочутті, працездатності спортсменів, а як наслідок на змагальній результативності.

Мета дослідження - вивчити вплив зміни часових поясів на динаміку психофізіологічних показників кваліфікованих фристайлістів.

Методи дослідження. Були використані наступні методи дослідження: теоретичний аналіз і узагальнення даних науково-методичної літератури; педагогічний експеримент, педагогічне тестування, анкетування; фізіологічні та психологічні тести; методи математичної статистики. У досліджені брали участь десять кваліфікованих фристайлістів, з них 5 представників жіночої та 5 представників чоловічої статі, вік спортсменів від 18 до 25 років.

Для 3'ясування впливу зміни часового поясу на стан організм кваліфікованих фристайлістів ми використали декілька способів. Перший передбачав опитування за розробленою нами анкетою. Анкетування проводили під час навчально-тренувального збору в грудні 2018 року. За результатами анкетування з'ясували: зміни в організмі, які відчувають спортсмени при перельоті в західному та східному напрямку за умов різниці часу \pm 4-8 годин; критичні дні, терміни відновлення основних показників та функцій організму.

Для вивчення впливу зміни часового поясу на функціональні показники кваліфікованих фристайлістів ми провели педагогічний експеримент який передбачав психологічне опитування та проведення контрольних тестів.

Перед виїздом на навчально-тренувальний збір та змагання в США (лютий 2019) ми визначили: фізичну працездатність (за допомогою Гарвардського степ-тесту); адаптаційний потенціал (за методикою Р. М. Баєвського); тест на координацію (визначення здібностей до відтворення та диференціювання динамічних зусиль нижніми кінцівками); анкетування для самооцінки активності, самопочуття та настрою за методикою “САН” [11]. Ті ж виміри провели в 1, 3, 5 та 7-ий день перебування на зборах в США (курорт Deer Valley resort, містечко Park City, штат Юта, різниця в часі мінус 9 годин).

Результати дослідження опрацьовували методами математичної статистики: середнє арифметичне значення $(\overline{\mathrm{x}})$; похибка середнього арифметичного $(\mathrm{m})$; середнє квадратичне відхилення; вірогідність різниці середніх величин проводилась за критерієм Стьюдента (t).

Результати дослідження. Аналіз даних анкетного опитування (табл.1) показав, що всі респонденти дотримуються єдиної точку зору щодо важливості дослідження даної проблеми. Встановлено, що всі опитані фристайлісти мали досвід перебування на тренувальних зборах, змаганнях в інших часових поясах. Вісімдесят відсотків досліджуваних неодноразово перебували на зборах, змаганнях в іншому часовому поясі, $\mathrm{i}$ лише 20\% мають незначний досвід (1-2 рази). Сімдесят відсотків спортсменів мали досвід зміни часових поясів як на захід, так і на схід, при різниці часу 6-8 годин, 30\% лише брали участь у зборах та змаганням при зміні часових поясів на схід при різниці 6-8 годин (Казахстан).

Аналіз суб’єктивних показників стану організму спортсменів дав можливість отримати дані про зміну самопочуття, настрою, працездатності, фізичних та технічних кондицій, бажання тренуватися, сну, апетиту.

Негативні зміни в організмі при зміні часових поясів відчуває $80 \%$ опитаних фристайлістів, 20\% - частково і вони мали значний попередній досвід (до п'яти років) тренувань та змагань в інших часових поясах. 
Результати опитування кваліфікованих фристайлістів, \%

\begin{tabular}{|l|c|c|c|}
\hline \multicolumn{1}{|c|}{ Зміст запитання } & Tак & Ні & Частково \\
\hline $\begin{array}{l}\text { Чи важливим є вивчення впливу зміни часових поясів на } \\
\text { фізину працездатність? }\end{array}$ & 100 & & \\
\hline $\begin{array}{l}\text { Чи маєте Ви досвід перебування на тренувальних зборах, } \\
\text { змаганнях в інших часових поясах? }\end{array}$ & 80 & 20 & \\
\hline $\begin{array}{l}\text { Чи відчуваєте Ви негативні зміни в організмі при зміні } \\
\text { часових поясів? }\end{array}$ & 80 & & 20 \\
\hline $\begin{array}{l}\text { Чи відчуваєте Ви відсутність бажання тренуватися при зміні } \\
\text { часових поясів (різниця більше 4 год)? }\end{array}$ & 20 & 50 & 30 \\
\hline $\begin{array}{l}\text { Чи відчуваєте Ви зниження фізичної працездатності при зміні } \\
\text { часових поясів (різниця більше 4 год)? }\end{array}$ & 80 & 20 & \\
\hline $\begin{array}{l}\text { Чи відчуваєте Ви погіршення якісних сторін рухової діяль- } \\
\text { ності при зміні часових поясів (різниця більше 4 год)? }\end{array}$ & 70 & 10 & 20 \\
\hline $\begin{array}{l}\text { Чи відчуваєте Ви збереження або покращення своїх можливос- } \\
\text { тей (фізичних кондицій, техніки виконання вправ) при зміні } \\
\text { часових поясів? }\end{array}$ & 90 & 10 \\
\hline $\begin{array}{l}\text { Чи практикуєте Ви зменшення фізичного навантаження в } \\
\text { перший період перебування в іншому часовому поясі на тре- } \\
\text { нувальних зборах? }\end{array}$ & 90 & 10 \\
\hline $\begin{array}{l}\text { Чи практикуєте Ви активний відпочинок в перший період пе- } \\
\text { ребування в іншому часовому поясі на тренувальних зборах? }\end{array}$ & & 10 \\
\hline
\end{tabular}

На запитання: “Які саме зміни Ви відчуваєте?” респонденти відповіли наступним чином: порушення сну $-100 \%$; погіршення самопочуття $-90 \%$; відсутність апетиту $-80 \%$ (особливо серед дівчат); погіршення настрою - $40 \%$.

На запитання: "Чи відчуваєте Ви інколи відсутність бажання тренуватися при зміні часових поясів?”, відповіді були такими: 20\% - так, 50\% - ні та 30\% - частково.

Більшість кваліфікованих фристайлістів (80\%) відчувають зниження фізичної працездатності при зміні часових поясів і лише $20 \%$ - частково (це також були спортсмени, які мали значний досвід зміни часових поясів). Погіршення якісної сторони рухової діяльності (техніки, координації рухів) виявлено у $70 \%$ опитаних, 20\% зазначили часткові зміни, а у10\% жодних змін не відбувалося.

Більшість фристайлістів (70\%) зазначили, що їхньому організму потрібно 5-7 днів для адаптації до зміни часового поясу. Решту (30\%) не змогли дати конкретної відповіді.

Дев'яносто відсотків опитаних спортсменів практикує зменшення обсягу фізичного навантаження (в основному за рахунок інтенсивності) в перший період (1- 4 день) перебування в іншому часовому поясі на тренувальних зборах решту (10\%) лише частково. Десять відсотків фристайлістів зазначили, що практикують активний відпочинок в перший період (1-4 день) перебування в іншому часовому поясі на тренувальних зборах, решту $(90 \%)$ - не використовує.

Щодо питання: "В який день зміни часового поясу Ви почуваєте себе найгірше?”, більшість респондентів (80\%) відповіли, що це відбувається на 3-4, а 20\% - на 4-5 день. Важливо було встановити з якого дня при зміні часового поясу відбувається нормалізація основних функцій організму. Як виявилося, сон нормалізується на 6-7; самопочуття - 4-5; апетит - 6; фізичні кондиції - -5; технічні спроможності та координація рухів - на 6-7 день.

Опитування кваліфікованих фристайлістів та їх тренерів дозволило з'ясувати, що більшість спортсменів в перші дні перебування в нових умовах відчувають психо- 
емоційний дискомфорт. Перш за все, це відображається на характері сну, який часто стає неповноцінним. Зокрема, пробудження настає в 3-5 годині ранку, а відтак, о 16-17 годині настають прояви сонливості за місцевим часом. 3 першого по четвертий день у спортсменів (особливо в дівчат) знижується апетит. Найбільше це відчувається увечері, вночі ж часто з'являється відчуття голоду. Покращання апетиту спостерігається на шосту добу адаптації.

Результати оцінки функціонального стану кваліфікованих фристайлістів представлені у табл. 2.

Таблиия 2

Динаміка показників функціонального стану кваліфікованих фристайлістів при зміні часового поясу

\begin{tabular}{|l|c|c|c|c|c|}
\hline & $\begin{array}{c}1 \\
\text { Етапид тестування }\end{array}$ & $\begin{array}{c}2 \\
\text { (в день } \\
\text { пиїздом) }\end{array}$ & $\begin{array}{c}3 \\
\text { (на третій } \\
\text { день) }\end{array}$ & $\begin{array}{c}4 \\
\text { (на п'ятий } \\
\text { день) }\end{array}$ & $\begin{array}{c}5 \\
\text { (на сьомий } \\
\text { день) }\end{array}$ \\
\hline & $\overline{\mathrm{x}} \pm \mathrm{m}$ & $\overline{\mathrm{x}} \pm \mathrm{m}$ & $\overline{\mathrm{x}} \pm \mathrm{m}$ & $\overline{\mathrm{x}} \pm \mathrm{m}$ & $\overline{\mathrm{x}} \pm \mathrm{m}$ \\
\hline $\begin{array}{l}\text { Гантрольні тести } \\
\text { тест, у.о. }\end{array}$ & $110,1 \pm 7,6$ & $101,1 \pm 5,4$ & $89,1 \pm 6,4^{*}$ & $105,3 \pm 10,3$ & $108,3 \pm 8,5$ \\
\hline $\begin{array}{l}\text { Адаптаційний } \\
\text { потенціал, у.о. }\end{array}$ & $2,02 \pm 0,3$ & $2,38 \pm 0,33$ & $2,82 \pm 0,23^{*}$ & $2,3 \pm 0,35$ & $2,11 \pm 0,46$ \\
\hline Координація рухів, см & $6,1 \pm 1,1$ & $9,3 \pm 1,8$ & $16,1 \pm 2,3^{*}$ & $12,5 \pm 1,8$ & $7,3 \pm 1,3$ \\
\hline
\end{tabular}
$\mathrm{p} \leq 0,05$.

Примітка. * - наявність достовірної різниці між 1 та 3 етапами тестування на рівні

Вихідні дані перед виїздом становили $110,1 \pm 14,6$ ум.од., цей показник характеризувався як високий. Перший день перебування в іншому часовому поясі працездатність зменшилася на 8,5\%. Найнижчий рівень фізичної працездатності (показник зменшився на $21,1 \%(\mathrm{p} \leq 0,05))$ у фристайлістів ми зафіксували на третій день перебування. І лише на сьомий адаптації показник працездатності фристайлістів (108,3 $\pm 12,5$ ум.од.) наблизився до вихідного показника перед вильотом (p>0,05).

За результатами дослідження адаптаційного потенціалу (АП) встановлено, що напередодні вильоту він становив $2,02 \pm 0,3$ ум.од. і свідчив про його задовільну величину. У перший день перебування в США АП зменшився на 16,4\%. Найбільше зниження АП (на 33\%) було зафіксовано на третій день перебування ( $\leq \leq 0,05)$, що вказувало на

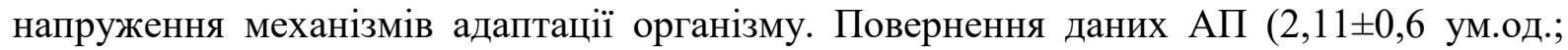
$(\mathrm{p}>0,05)$.) в зону задовільної адаптації ми спостерігали на сьомий день навчальнотренувального збору.

Значна різниця у часовому поясі (мінус 9 годин) впливає на координацію рухів, що негативно відображається на здійсненні складнокоординаційних рухових дій фристайлістів. Так, похибка у руховому тесті “Стрибок в довжину на задану відстань”, який вимагає прояву здатності до диференціювання просторово-динамічних параметрів рухової діяльності, перед вильотом складала $6,1 \pm 1,1$ см. Після перельоту збільшилася на

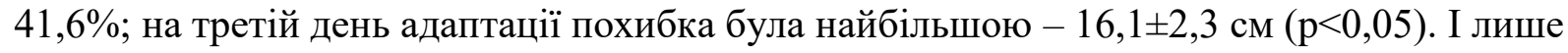
на сьомий день похибка при диференціюванні стрибка в довжину наблизилася до вихідного показника і становила 7,3 $\pm 1,3 \mathrm{~cm}(\mathrm{p}>0,05)$.)

Результати дослідження психологічного статусу спортсменів наведені в табл. 3. Як видно з цих даних, більшість кваліфікованих фристайлістів оцінили свій психологічний стан $з$ підвищеним самопочуттям і настроєм та нормальною активністю. 
Таблиия 3

Показники самопочуття, активності, настрою кваліфікованих фристайлістів при зміні часового поясу (за опитувальником САН)

\begin{tabular}{|l|c|c|c|}
\hline \multirow{2}{*}{ Період тестування } & \multicolumn{3}{|c|}{ Показники } \\
\cline { 2 - 4 } & самопочуття & активність & настрій \\
\hline Перед виїздом & підвищене & нормальна & підвищений \\
\hline В день приїзду & нормальне & знижена & нормальний \\
\hline На третій день & знижений & знижена & нормальний \\
\hline На п’ятий день & нормальне & нормальна & нормальний \\
\hline На сьомий день & нормальне & підвищена & підвищений \\
\hline
\end{tabular}

Після перельоту більшість спортсменів відчували знижену активність, але мали нормальний настрій та самопочуття. Найбільш критичним періодом був третій день адаптації до нового часового поясу, зокрема, ми зафіксували у фристайлістів знижений рівень активності та самопочуття. Відновлення цих показників відбувалося лише через тиждень адаптації до нового часового поясу.

Дискусія. В роботах як вітчизняних, так зарубіжних авторів [9, 10] основна увага щодо переміщення спортсменів у часових поясах здебільшого висвітлюються питання, поовязані з дезадаптаційним процесами в організмі представників різних видів спорту зрушенням, які зумовленні різницею у часовому поясі Як правило розглядаються особливості цих явищ у представників швидкісних, швидкісно-силових видів, спортивних ігор, та спортсменів аеробних видів спорту (лижників, біатлоністів, плавців, тенісистів тощо) $[8,9]$. Проте, чи не найбільшою проблемою щодо адаптації в умовах зміни часових поясів зазнають представники складно координаційних видів спорту, зокрема і фристайлісти $[1,3]$. Цілком очевидни $\epsilon$, те, що зміна циркадних ритмів призводить до десинхронізації нервовоих процесів, як лежать в основі управляння координацією рухів. У зв'язку з цим необхідно розширити спектр досліджень щодо динаміки адаптації спортсменів складно координаційних спортивних дисциплін до зміни різних часових поясів і на цій основі здійснити визначення оптимального часу для виходу на пік готовності до головних змагань.

Висновок. Під час зміни часових поясів у кваліфікованих фристайлістів відбувається погіршення психофізіологічного стану, а саме: знижується фізична працездатність, здатність до точного виконання технічних елементів, координація рухів; погіршується сон, апетит, самопочуття та настрій. Як правило нормалізація всіх показників наступає після сьомого дня перебування в новому часовому поясі.

1. Аблаев Е. Цільова програма підготовки національної збірної команди України з фристайлу до участі у XXIV зимових Олімпійських іграх 2022 року у м. Пекін (Китай). Міністерство молоді та спорту України. Київ, 2019. 17 с.

2. Багнетова Е. Гигиена физического воспитания и спорта : курс лекций : учеб. пособие. Ростов н/Д: Феникс, 2009. 251c.

3. Грабик Н. Структура і зміст спортивної підготовки могулістів. Фізична культура, спорт та здоров'я нації: Зб. наук. праць. Вінниця, 2009; 8(2): 43-48.

4. Иорданская ФА. Особенности временной адаптации при перелетах на восток и запад, средства коррекции и профилактики десинхроноза. Теория и практика физ. культуры. 2001; 3: 18-24.

5. Коц ЯМ. Смена климато-поясных условий. Физиология спорта. М.: ФИС. 2002; 245-258.

6. Панфилов ОП. Адаптационная перестройка спортсменов при перелете в западном и восточном направлении. Теория и практика физ. культуры. 1991; 5: 33-34.

7. Пенигин АС. Структура й содержание многолетней подготовки квалифицированних спортсменовфристайлистов. Мир спорта. 2013; 3: 3-7.

8. Платонов ВН. Общая теория подготовки спортсменов в олимпийском спорте. К.: Олимп. Лит. 1997; 537-544. 
Грабик Надія, Грубар Ірина, Заверуха Назар. Вплив зміни часових поясів на психофізіологічний стан ...

9. Платонов ВН, Булатова ММ. Десинхронизация циркадных ритмов организма и временная адаптация спортсменов после дальних перелетовю Совершенствование системы подготовки спортсменов Украины к Олимпийским играм: Сб. науч. трудов. К.: Абрис. 1997; 3-14.

10. Португалов СН. Климато-поясная дезадаптация. Лекарства и БАД в спорте. М.: Литтера. 2003; 183- 192.

11. Сборник психологических тестов. Часть I: Пособие. Сост. Е.Е.Миронова. Мн.: Женский институт ЭНВИЛА, 2005; 19-20.

12. Розенфельд АС. Стресс и некоторые проблемы адаптационных перестроек при спортивных нагрузках. Теория и практика физ. культуры. 2004; 4: 39-44.

\section{References}

1. Ablaev E. Tsilova prohrama pidhotovky natsionalnoi zbirnoi komandy Ukrainy $\mathrm{z}$ frystailu do uchasti $\mathrm{u}$ XXIV zymovykh Olimpiiskykh ihrakh 2022 roku u m. Pekin (Kytai). Ministerstvo molodi ta sportu Ukrainy. 2019. 17 s.

2. Bahnetova E. Hyhyena fyzycheskoho vospytanyia y sporta : kurs lektsyi : ucheb. Posobye. Rostov n/D: Fenyks, 2009. $251 \mathrm{~s}$.

3. Hrabyk N. Struktura i zmist sportyvnoi pidhotovky mohulistiv. Fizychna kultura, sport ta zdorovia natsii: zb. nauk. prats. Vinnytsia, 2009; 8(2): 43-48.

4. Yordanskaia FA. Osobennosty vremennoi adaptatsyy pry pereletakh na vostok y zapad, sredstva korrektsyy y profylaktyky desynkhronoza. Teoryia y praktyka fyz. kultury. 2001; 3: 18-24.

5. Kots YaM. Smena klymato-poiasnykh uslovyi. Fyzyolohyia sporta. M.: FYS. 2002; 245-258.

6. Panfylov OP. Adaptatsyonnaia perestroika sportsmenov pry perelete v zapadnom y vostochnom napravlenyy. Teoryia y praktyka fyz. kultury. 1991; 5: 33-34.

7. Penyhyn AS. Struktura y soderzhanye mnoholetnei podhotovky kvalyfytsyrovannykh sportsmenovfrystailystov. Myr sporta. 2013; 3: 3-7.

8. Platonov VN. Obshchaia teoryia podhotovky sportsmenov v olympyiskom sporte. K.: Olymp. Lyt. 1997; 537-544.

9. Platonov VN, Bulatova MM. Desynkhronyzatsyia tsyrkadnykh rytmov orhanyzma y vremennaia adaptatsyia sportsmenov posle dalnykh pereletoviu Sovershenstvovanye systemы podhotovky sportsmenov Ukrayny k Olympyiskym yhram: Sb. nauch. trudov. K.: Abrys. 1997; 3-14.

10. Portuhalov SN. Klymato-poiasnaia dezadaptatsyia. Lekarstva y BAD v sporte. M.: Lyttera. 2003; $183-92$.

11. Sbornik psihologicheskih testov. Chast I: Posobie. Sost. E.E.Mironova. Mn.: Zhenskiy institut ENVILA, 2005; 19-20.

12. Rozenfeld AS. Stress y nekotorye problemy adaptatsyonnykh perestroek pry sportyvnыkh nahruzkakh. Teoryia y praktyka fyz. kultury. 2004; 4: 39-44.

Цитування на цю статтю:

Грабик НМ, Грубар ІЯ, Заверуха НР. Вплив зміни часових поясів на психофізіологічний стан кваліфікованих фристайлістів. Вісник Прикарпатського університету. Серія: Фізична культура. 2020 Листоп 03; 35: $17-24$

\begin{tabular}{|c|c|}
\hline Відомості про автора: & Information about the author: \\
\hline $\begin{array}{l}\text { Грабик Надія Михайлівна - кандидат наук з фі- } \\
\text { зичного виховання та спорту, доцент кафедри тео- } \\
\text { ретичних основ і методики фізичного виховання, } \\
\text { Тернопільський національний педагогічний універ- } \\
\text { ситет імені Володимира Гнатюка (Тернопіль, } \\
\text { Україна) }\end{array}$ & $\begin{array}{l}\text { Hrabyk Nadiya Mykhaylivna - Candidate of Sciences } \\
\text { in Physical Education and Sports, Associate Professor } \\
\text { of the Department of Theoretical Foundations and } \\
\text { Methods of Physical Education, Volodymyr Hnatiuk } \\
\text { Ternopil National Pedagogical University (Ternopil, } \\
\text { Ukraine) }\end{array}$ \\
\hline \multicolumn{2}{|l|}{$\begin{array}{l}\text { e-mail: ngrabyk@gmail.com } \\
\text { https://orcid.org/0000-0002-8882-9782 }\end{array}$} \\
\hline $\begin{array}{l}\text { Грубар Ірина Ярославівна - кандидат наук з фізич- } \\
\text { ного виховання та спорту, доцент кафедри теоре- } \\
\text { тичних основ і методики фізичного виховання, } \\
\text { Тернопільський національний педагогічний універ- } \\
\text { ситет імені Володимира Гнатюка (Тернопіль, } \\
\text { Україна) }\end{array}$ & $\begin{array}{l}\text { Hrubar Iryna Yaroslavivna - Candidate of Sciences } \\
\text { in Physical Education and Sports, Associate Professor } \\
\text { of the Department of Theoretical Foundations and } \\
\text { Methods of Physical Education, Volodymyr Hnatiuk } \\
\text { Ternopil National Pedagogical University (Ternopil, } \\
\text { Ukraine) }\end{array}$ \\
\hline $\begin{array}{l}\text { e-mail: Hrubar@ukr.net } \\
\text { https://orcid.org/0000-0002-0809-1299 }\end{array}$ & \\
\hline
\end{tabular}




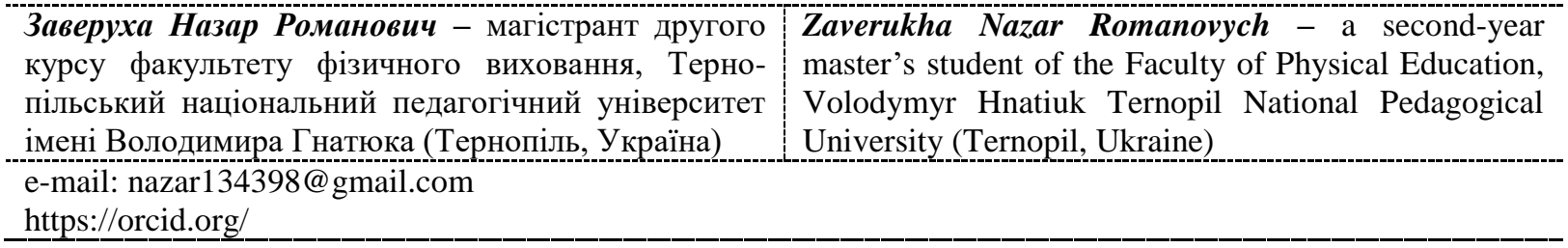

\title{
АКТУАЛЬНІСТЬ ТА ПЕРЕДУМОВИ РОЗРОБЛЕННЯ ГАЛУЗЕВОЇ РАМКИ КВАЛІФІКАЦІЙ У СИСТЕМІ СПОРТУ В УКРӒ̈НІ
}

\begin{abstract}
Мета. Узагальнити сучасний масив наукових знань та передовий міжнародний досвід щяодо актуальності та передумов розроблення галузевої рамки кваліфікаиій у системі спорту в Україні. Методи. Використано такі методи теоретичного дослідження: аналіз наукової літератури та документальних джерел, інформаційних ресурсів мережі Інтернет, передового зарубіжного та вітчизняного досвіду; поєднання логічного та історичного аналізу; системний аналіз; порівняння та зіставлення; функціонально-структурний аналіз. Результати. Визначено, щяо актуальність розроблення галузевої рамки кваліфікацій у системі спорту в Украӥні детермінована необхідністю: спрощення визнання кваліфікацій на начіональному та міжнародному ринках праці; впровадження сучасного концепту навчання впродовж життя; інтегрування, оцінювання та порівняння результатів навчання, досягнутих у різних формах здобуття освіти та їх поєднанні; модернізації кваліфікаційних характеристик професій у відповідності до Національної рамки кваліфікацій та специфіки професійної діяльності. Встановлено, щзо в системі спорту та активного відпочинку в Украйні наявні теоретико-методологічні, нормативноправові та організаційні передумови для розроблення галузевої рамки кваліфікацій. Висновок. В Украӥні для системи спорту та активного відпочинку актуальним є розроблення галузевої рамки кваліфікацій $i$ для цүього сформовані відповідні передумови.
\end{abstract}

Ключові слова: кваліфікація, система спорту, професії, галузева рамка, актуальність, передумови.

The aim. We aim at generalizing the modern array of scientific knowledge and advanced international experience on the topicality and prerequisites for the development of the sectoral qualifications framework in the sports system in Ukraine. Methods. The following methods of theoretical research are used, i.e. analysis of scientific literature and documentary sources, Internet information resources, advanced foreign and domestic experience; combination of logical and historical analysis; system analysis; comparison and juxtaposition; functional and structural analysis. Results. It is established that the urgency of developing a sectoral qualifications framework in the sports system of Ukraine is determined by the need to simplify the recognition of qualifications in the national and international labour markets; introduction of a modern concept of lifelong learning; integration, evaluation and comparison of learning outcomes achieved in different forms of education and their combination; modernization of qualifications characteristics of professions in accordance with the National Qualifications Framework and the specifics of professional activity. It is established that in the system of sports and active recreation in Ukraine there are theoretical and methodological, regulatory and organizational prerequisites for the development of the sectoral qualifications framework. Conclusion. The development of the sectoral qualifications framework is topical for the system of sports and active recreation in Ukraine, thus, the relevant preconditions have been formed for this purpose.

Keywords: qualification, sports system, professions, qualifications framework, topicality, preconditions.

Постановка проблеми й аналіз результатів останніх досліджень. В Україні протягом останніх трьох років активно формується національна система кваліфікацій. Серед іiі важливих компонентів виділяють: Національну рамку кваліфікацій; галузеві рамки кваліфікацій; професійні стандарти; інституції, котрі формують політику у сфері професійних кваліфікацій та відповідають за їх впровадження; інституції, що відповідають за розроблення та контроль щодо дотриманням професійних стандартів; інституції, що здійснюють верифікацію професійних стандартів, їх присвоєння та визнання кваліфікацій, здобутих в інших країнах, тощо [12]. 